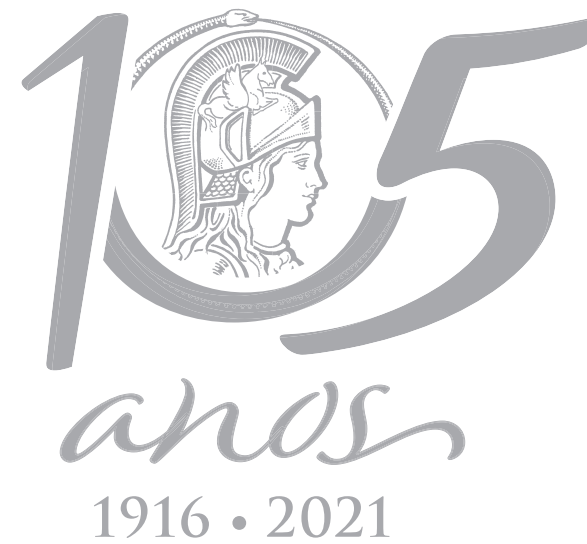

$1916 \cdot 2021$

\title{
First report of a Copitarsia species (Lepidoptera. Noctuidae) damaging soybean crops, with identification key to most common pest species
}

\author{
GERMÁN SAN BLAS, MARÍA C. TULLI \& DORA M. CARMONA
}

\begin{abstract}
The genus Copitarsia Hampson (Lepidoptera. Noctuidae) includes agricultural pests of at least 48 crop plants and they are distributed from Mexico to southern South America. In South America, from Venezuela to Chile and Argentina, Copitarsia incommoda (Walker) is one of the most economic important species of the genus. In this work, we record for the first time for Copitarsia, and specifically for $C$. incommoda, larvae feeding on soybean leaves and beans. Also, this species is recorded for the first time for Argentina, feeding on lucerne crops. Finally, we provide a larval identification key for most common noctuoids soybean pests of South America, including C. incommoda. This will be helpful for identify this species in soybean crops without the need of larvae rearing.
\end{abstract}

Key words: Argentina, Copitarsia incommoda, lucerne, South America.

\section{INTRODUCTION}

The genus Copitarsia Hampson (Lepidoptera. Noctuidae) includes 26 species distributed from Mexico to southern South America (Gould et al. 2013, Pogue 2014). Larvae of this genus are polyphagous, feeding on 48 crop plants including: potatoes (Solanum tuberosum L.), beet (Beta vulgaris L.), lucerne (Medicago sativa L.), sunflower (Helianthus annuus L.), tomato (Solanum lycopersicum L.), and corn (Zea mays L.) (Gould et al. 2013). Of all the species of the genus, only six are considered of economic importance: C. humilis (Blanchard), C. naenoides (Butler), C. corruda Pogue \& Simmons, C. decolora (Guenée), C. gibberosa Pogue, and C. incommoda (Walker) (Gould et al. 2013).

Copitarsia incommoda is one of the most economic important species of the genus (Simmons \& Pogue 2004), distributed along western South America, from Venezuela to central part of Chile and Argentina (Pogue 2014). In Argentina, individuals of $C$. incommoda have been confirmed in Buenos Aires, La Rioja, Mendoza, Neuquén, and San Juan (Pogue 2014). Simmons \& Pogue (2004) provided a detailed review of this species, including taxonomical problems, hosts, distribution, and biology.

Noctuids larvae collected and reared on soybean fields of Buenos Aires, Argentina, revealed not only presence of $C$. incommoda in this crop but also important damages to leafs and beans. This article provides the first record for the genus Copitarsia and particularly for C. incommoda, damaging soybean and first record for Argentina damaging lucerne. Finally, an identification key including South American most important Noctuoidea soybean pest species, including C. incommoda, is presented. 


\section{MATERIALS AND METHODS}

Samplings of Lepidoptera defoliator larvae were carried out twice a month, between January and March, 2018, in four soybean crops, in Balcarce, Buenos Aires province, Argentina. Plot 1 (-37.795000, -58.286111) was located in the research field "Reserva7" at the Estación Experimental Agropecuaria Balcarce, Instituto Nacional de Tecnología Agropecuaria (EEA Balcarce, INTA). This plot was surrounded by lucerne and grass pastures. Plots 2 to 4 $(-37.752778,-58.295278 ;-37.757500,-58.302778$; and $-37.766667,-58.302778$, respectively) were located in the Unidad Integrada Balcarce: EEA Balcarce, INTA-Facultad de Ciencias Agrarias, Universidad Nacional de Mar del Plata (UNMdP). These plots were surrounded by annual summer crops (Fig. 1).

In the four plots, samples were taken with sweep net. In the laboratory of the Zoologia Agricola of the Unidad Integrada Balcarce, larvae collected were identified, photographed, and reared to adult with soybean leaves and beans as food. Dissections of genitalia were conducted as described in Lafontaine (2004) and San Blas (2014). For identification of specimens, the key in Pogue (2014) was followed, from which taxon concepts and taxonomic classification were also derived. Images of the genitalia were taken with a Carl Zeiss Axiocam ERc5s digital camera attached to a Carl Zeiss Stemi 508 stereoscopic microscope. Those images were taken at multiple focal planes and then combined into a single image with the free software CombinezP (Hadley 2019) and enhanced with image editing software. The map was prepared using Google ${ }^{\mathrm{TM}}$ Earth Pro. Characters for identification key were taken from: Crumb (1956) for Anticarsia gemmatalis Hübner, Barrionuevo (2011) for Rachiplusia nu (Guenée), Barrionuevo \& San Blas (2016) for Chrysodeixis includens (Walker), Pogue (2002) and Vera et al.

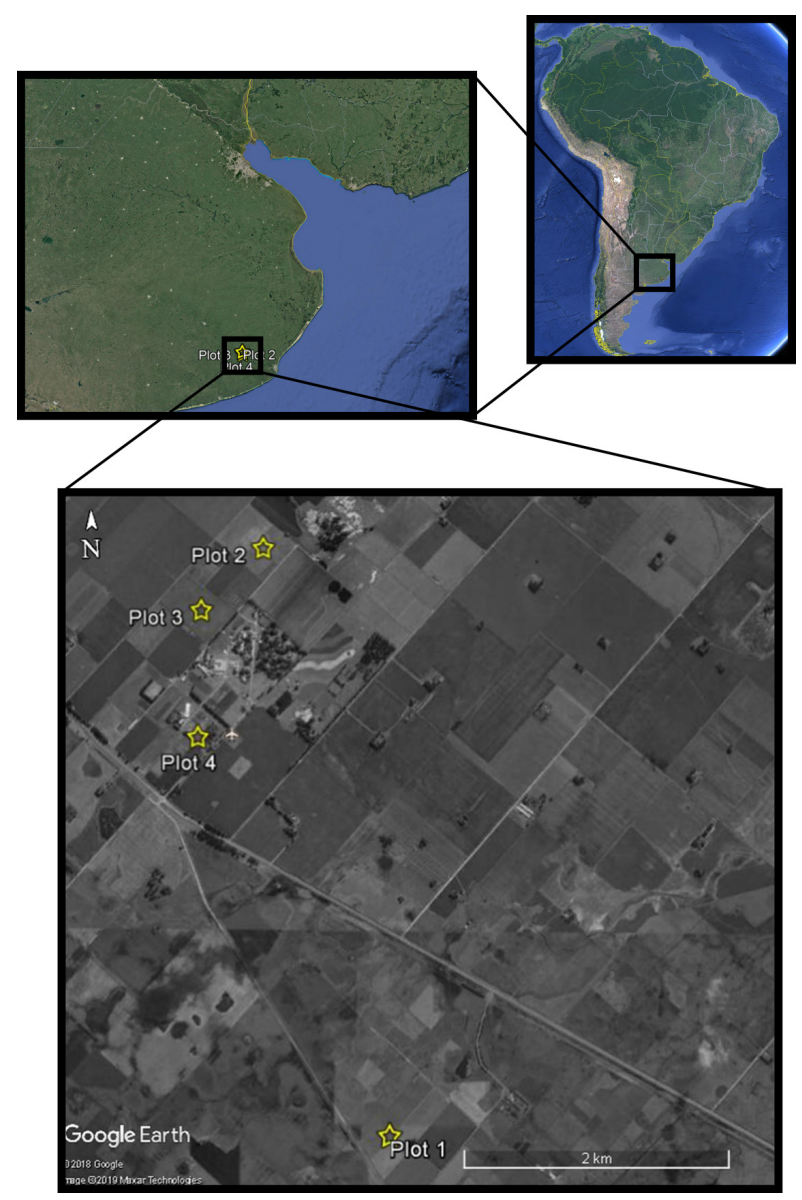

Figure 1. Geographic location of the four sampling plots.

(2018) for Spodoptera Guenée, and Pogue (2011) for C. incommoda.

\section{RESULTS AND DISCUSSION}

Sampling effort resulted in 463 Lepidoptera defoliator larvae collected, most of them belonging to typical soybean pest species, including 391 specimens of Rachiplusia nu, one of the most common defoliator Lepidoptera related to this crop in Buenos Aires province (Carmona et al. 1995, 2009, Luna \& Sánchez 1999). Additionally, $10 \%$ of the specimens collected (45 larvae) corresponded to C. incommoda (Figs. 2-5). This represents the first record of 


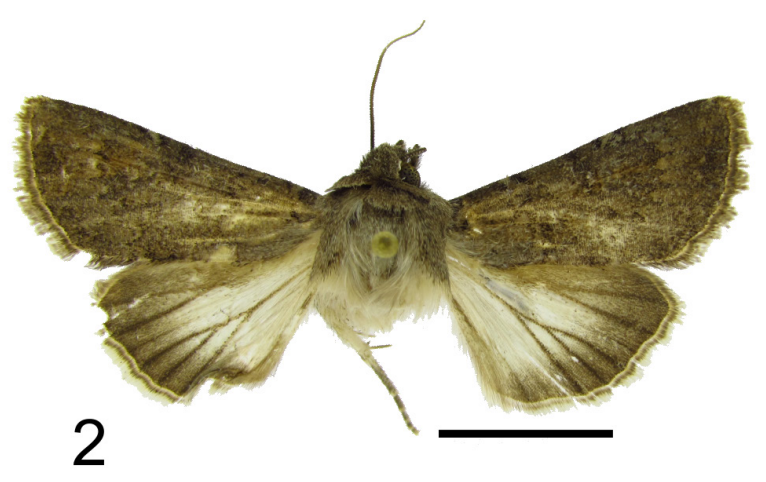

\author{
Figures 2-5. Adult of \\ Copitarsia incommoda \\ reared from larvae: 2 . \\ male adult; 3. detail of \\ basal area of the vesica \\ of aedeagus; 4. male \\ genitalia; 5 . aedeagus. \\ Adult scale bar $=10 \mathrm{~mm}$.
}

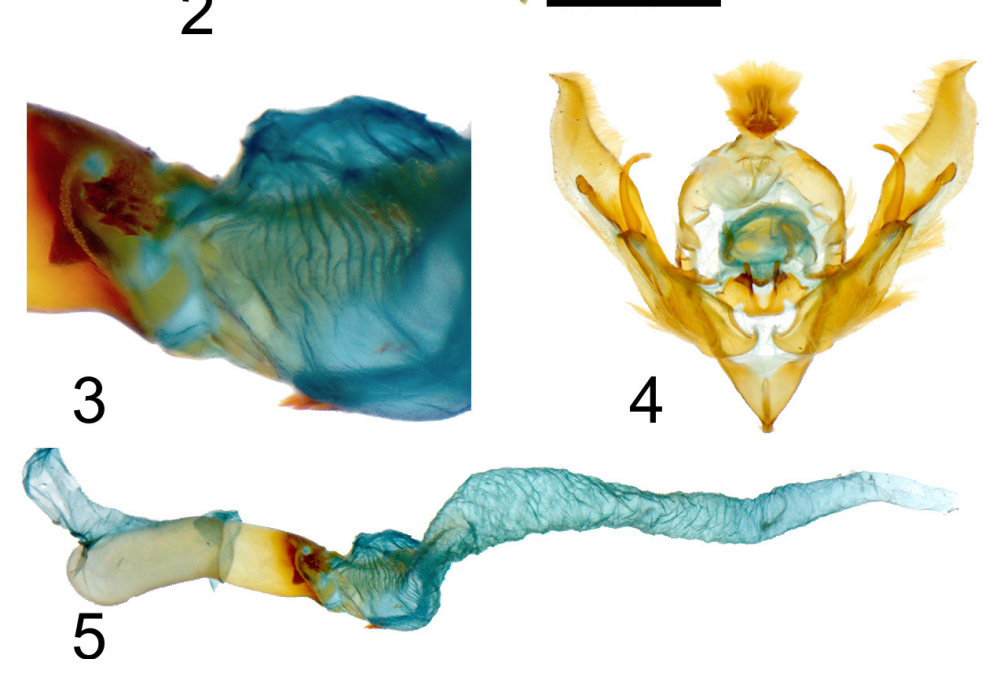

a Copitarsia species, and particularly of $C$. incommoda species, damaging soybean crop.

Gould et al. (2013) explained that the taxonomy of $\mathrm{C}$. incommoda is complicated, many times being named by an earlier name ( $C$. consueta (Walker)) or confused with C. decolora (also named as C. turbata (Herrich-Schäffer)) or with C. gibberosa. Thus, the hosts and distribution of this species are unclear. Gould et al. (2013) following papers with male genitalia drawings only, were able to limit the possible distribution of the species to western South America, from Colombia to Chile and Argentina, but they were not able to recover hosts species. Nonetheless, neither Gould et al. (2013) nor any other study (Pastrana 2004, Simmons \& Pogue 2004, Vennette \& Gould 2006) cited soybean as a host for any species of Copitarsia. This is consistent with the review by Formentini et al. (2015) that do not mention species of the genus
Copitarsia affecting soybean crops in Argentina, Brazil, Chile, or Uruguay.

The total abundance of $C$. incommoda was higher in plot 1 (29 larvae) than in plots 2, 3, and 4 , with records of 10, 5 and 1 larvae respectively. Copitarsia species are generally found feeding on lucerne crops in Chile (Pastrana 2004). The authors of this paper also found C. incommoda feeding on lucerne in La Pampa and Buenos Aires provinces, Argentina, which correspond to new host for this species for the country (1738173161 unpublished data). Since plot 1 was surrounded by lucerne crops, greater abundance of $C$. incommoda in this plot than in the other plots could be a consequence of migration of adults from lucerne to soybean. Nevertheless, successful rearing of this species with leaves and beans of soybean (Figs. 6-7), evidence the ability of this species to develop feeding exclusively on this crop. 


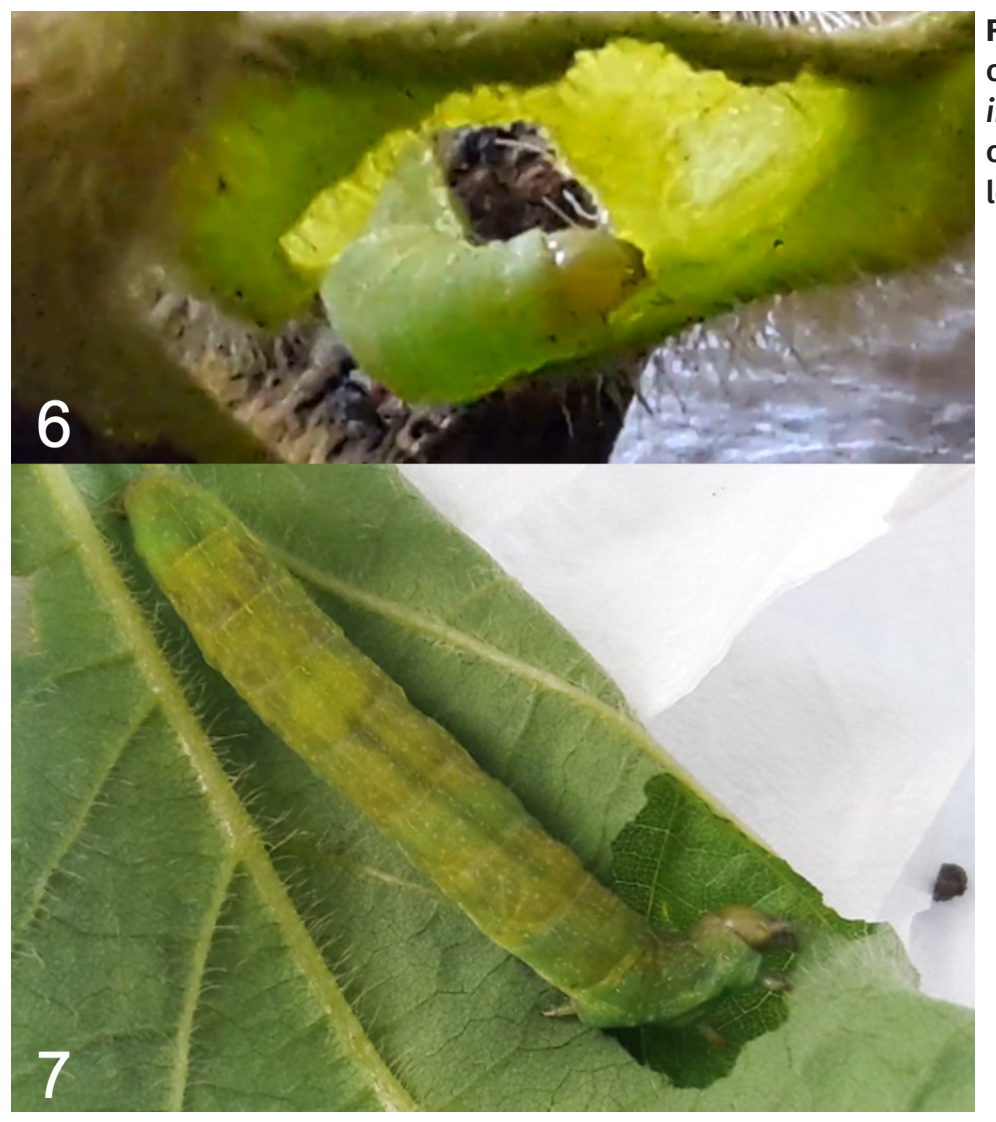

\author{
Figures 6-7. Larvae \\ of Copitarsia \\ incommoda feeding \\ on soybean on: 6 . \\ leaves and 7. beans.
}

Soybean is a constantly growing crop, with 125.67 million of hectares on 2018/2019 and 1 million more projected for next year (USDA 2019). Soybean cultivation is highly concentrated geographically, with only five countries (USA, Brazil, Argentina, India, and China) accounting for almost $85 \%$ of world output, and particularly southern South America (including Argentina, Brazil, Paraguay, Bolivia, and Uruguay) accounting for more than $50 \%$ of world output (USDA 2019). The soybean yield represents an important fraction of the incomes for each of these countries. Special caution to presence of larvae of this species should be taken, especially when crops are surrounded by lucerne. At present, there is no available key to differentiate C. incommoda larva from other species pest of soybean. Thus, in this study an identification key is provided to differentiate the most common pest species of the Noctuoidea superfamily related to soybean in South America, including C. incommoda.

Coloration pattern for C. incommoda was taken from Pogue's (2011) larvae description, but larvae founded in this study were extremely variable coloured, from light green with no differentiable lines, to almost black, with strong whitish lines (Fig. 8). This variability of colour pattern was not added to the key because further rearing of specimens and morphological and molecular analysis should be made to test their conspecificity.

\section{Key to differentiate larvae of the most common pest species of the Noctuoidea superfamily related to soybean in South America}

1- Thorax and abdomen with numerous long secondary setae-------- Spilosoma virginica (F.)

1'- Body without secondary setae----------2 

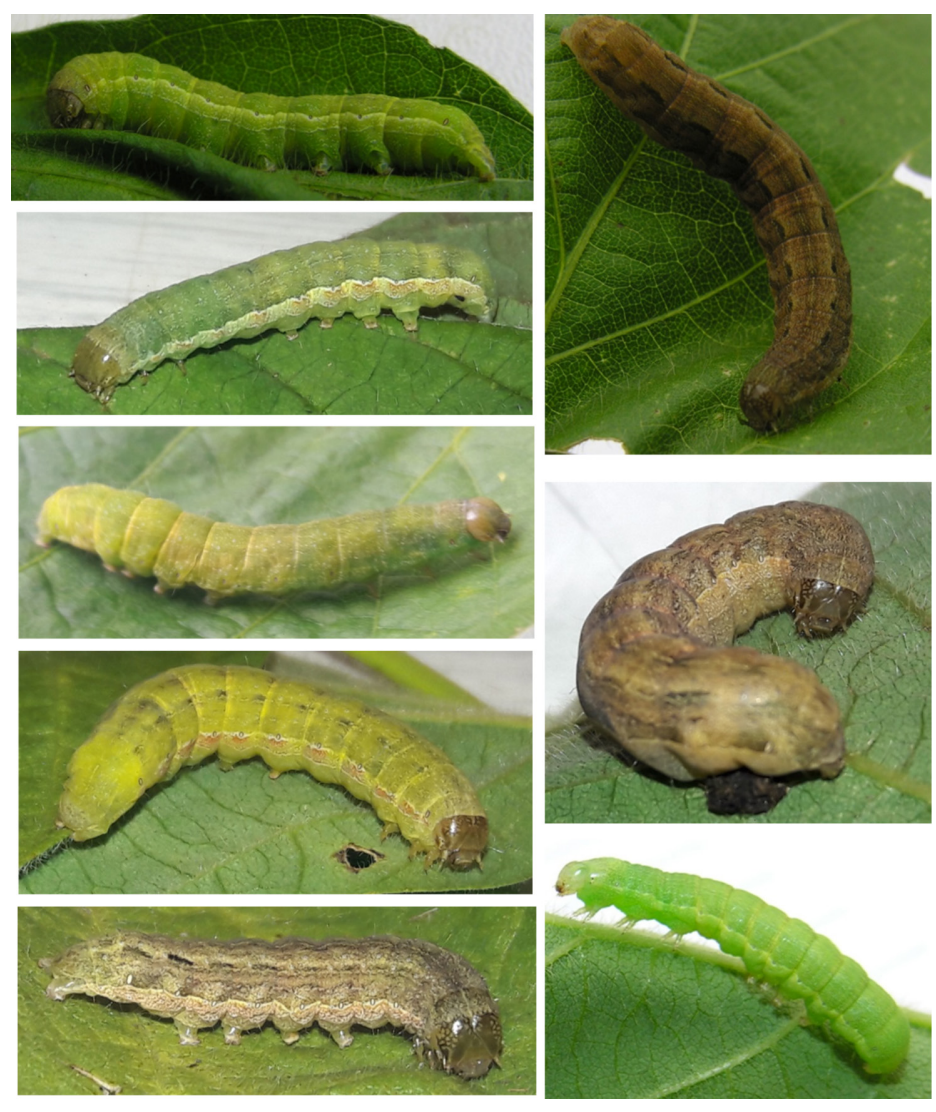

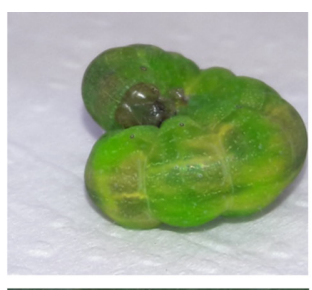

Figure 8. Coloration pattern for Copitarsia incommoda larvae found in soybean crop.
2- Abdomen with three pairs of prolegs (on A5-A6 and A10), sometimes with reduced, nonfunctional prolegs without crochets on A3-A4---3

2 '- Abdomen with five fully developed pairs of prolegs with crochets (on A3-A6 and A10)-----4

3- Abdomen with vestigial prolegs on A3-A4; setae SV1, SV2, SV3, and V1 equidistant and on separate pinnacles on A3-A4; tegument densely covered dorsally with light and dark tiny spines, not forming ventral rings. Larvae with variable colour pattern, more frequently from brightly light green to yellowish green, some specimens olive green or with two colours: dark green over supraspiracular area and light green below it; with four pairs of white continuous conspicuous lines of variable size.

\section{Chrysodeixis includens (Walker)}

3'- Abdomen without vestigial prolegs; SV1 and SV2 in the same pinaculum, SV3, and V1 in individual pinnacles, SV1-SV2 closer between them than with SV3 or V1 on A3-A4; tegument densely covered with black small spines, forming rings surrounding ventral setae. Larvae with variable colour pattern, more frequently from brightly light green to yellowish green, with two longitudinal dark green bands: one dorsal, between D1 setae of each segment and another supraspiracular, dorsal to lateral line; with four pairs of white conspicuous lines of variable size; some specimens with dark green or darkish colour pattern, without differentiable bands.---

\section{Rachiplusia nu (Guenée)}

4- Anal prolegs notably directed posteriorly, making the end of the abdomen looking like a "V"; SV3 present on A1. Larvae varying from green through dusky olivaceous gray to brown, with numerous longitudinal whitish lines; with whitish or yellowish transversal lines between most segments.

-Anticarsia gemmatalis Hübner 
4'- Anal prolegs not directed posteriorly; SV3 absent on A1---------------------------------5

5-Head with adfrontal area not differentiated; SD1 on T2 and T3 not connected to the associated tonofibrillary platelet by a minute sclerotized bar. Larvae head yellowish brown, with a variable degree of darker reticulate on the gena; overall body colour cream with a dark brown reticulate pattern extending to just below dorsal apex of spiracles; dorsal stripe faint, narrow; dorso-lateral stripe dark brown and consisting of a series of irregular shaped elongate dashes on A1-A8; pattern below spiracle and ventral surface a reduced amount of irregular dark brown reticulations; the dorsal surfaces of the thorax and abdomen have paired, subdorsal, irregular, elongate marks on the thorax and abdomen.-----Copitarsia incommoda (Walker)

5'- Head with adfrontal area outlined in white forming an inverted "Y"; SD1 on T2 and T3 connected to the associated tonofibrillary platelet by a minute sclerotized bar.-------------6

6- A8 with D1 and D2 pinnacles distinctly larger than on other segments; thorax and abdomen with light subspiracular band. Larvae overall colour from light brown, light green to dark green, D-group pinnacles easily seen at naked eye.-------Spodoptera frugiperda (Smith)

6'- D-group pinnacles uniform in size on abdominal segments; body without differentiable subspiracular band; D-group pinnacles not easily differentiable.--------------7

7- Thorax and abdomen with subdorsal band interrupted by white spots on center of each segment; blackish triangular spots dorsal to subdorsal line on each segment, distinctively larger on A8. Larvae overall colour from blackish to brown.--------Spodoptera cosmioides Walker

7'- Thorax and abdomen with subdorsal band continuous; blackish rhomboid spots dorsal to subdorsal line on each segment, distinctively larger on T3 and A8. Larvae overall colour from green to light brown. ---------Spodoptera eridania (Stoll)

\section{Acknowledgments}

We thank the Facultad de Ciencias Exactas y Naturales - Universidad Nacional de La Pampa (UNLPam), the Facultad de Ciencias Agrarias - Universidad Nacional de Mar del Plata (UNMdP), and Instituto Nacional de Tecnología Agropecuaria (INTA), which provided workspace and equipment. This study was supported by the Consejo Nacional de Investigaciones Científicas y Técnicas (CONICET). GSB thanks the Agencia Nacional de Promoción Científica y Tecnológica (ANPCYT) (PICT2016-0588) and the Universidad Nacional de La Pampa (UNLPam) (POIRE-2016-17), MCT thanks UNMdP (AGR 549/18) and INTA (PNCYO 1127034) for financial support. MCT also grateful to Diego Andres Martiarena for his helpful advice during this work.

\section{REFERENCES}

BARRIONUEVO MJ. 2011. Redescripción de los estados preimaginales de Rachiplusia nu (Lepidoptera: Noctuidae). Rev Soc Entomol Arge 70(3-4): 169-184.

BARRIONUEVO MJ \& SAN BLAS G. 2016. Redescription of immature stages of the soybean looper (Lepidoptera: Noctuidae: Plusiinae). Can Entomol 148(3): 247-259.

CARMONA D, LOPEZ R, GUIDO S \& VINCINI AM. 2009. Fluctuación poblacional e identificación especifica de las isocas medidoras en cultivos de soja del Sudeste Bonaerense. In: Actas XIII Jornadas Fitosanitarias Argentinas, Las termas de Rio hondo, Santiago del Estero, Argentina, Zoology section, p. 12.

CARMONA DM, MANETTI PL \& ABOT A. 1995. Relevamiento de insectos plaga y sus enemigos naturales en el cultivo de soja en el Sudeste Bonaerense. In: Actas III Congreso Argentino De Entomología, Mendoza, Argentina, p. 138.

CRUMB SE. 1956. The larvae of the Phalaenidae. Tech Bull - U S Dep Agric 1135: 1-356.

FORMENTINI AC, SOSA-GÓMEZ DR, PAULA-MORAES SV, BARROS NM \& SPECHT A. 2015. Lepidoptera (Insecta) associated with soybean in Argentina, Brazil, Chile and Uruguay. Cienc Rural 45(12): 2113-2120.

GOULD J, SIMMONS R, VENETTE R \& PEÑA J. 2013. Copitarsia spp.: biology and risk posed by potentially invasive lepidoptera from South and Central America. In: Peña 
JE (Ed). Potential invasive pests of agricultural crops, Invasive Series No 3. CAB International, Wallingford, United Kingdom, p. 160-182.

HADLEY A. 2019. CombineZP. Available from http:// micropics.org.uk/Czimps_web/CombineZP.msi [accessed 10 September 2019].

LAFONTAINE JD. 2004. The moths of America north of Mexico. Fascicle 27.1: Noctuidae (part) - Agrotini. The Wedge Entomological Research Foundation, Washington, D.C., United States of America.

LUNA G \& SÁNCHEZ N. 1999. Composición específica y abundancia de la comunidad de lepidopteros defoliadores en el noroeste de Buenos Aires, Argentina. Rev Soc Entomol Arge 58(2-4): 67-75.

PASTRANA JA. 2004. Los lepidópteros argentinos. Sus plantas hospedadoras y otros sustratos alimenticios. Sociedad Entomológica Argentina, Buenos Aires, Argentina, $334 \mathrm{p}$.

POGUE MG. 2002. A world revision of the genus Spodoptera Guenée:(Lepidoptera: Noctuidae). Mem Am Entomol Soc 43: 1-202.

POGUE MG. 2011. Larval description of Copitarsia incommoda (Lepidoptera: Noctuidae). Ann Entomol Soc Am 104(6): 1292-1297.

POGUE MG. 2014. A review of the Copitarsia decolora (Guenée) (Lepidoptera: Noctuidae) species complex with the description of a new species from Chile and Argentina. Neotrop Entomol 43: 143-153.

SAN BLAS G. 2014. Agrotis Ochsenheimer (Lepidoptera, Noctuidae): a systematic analysis of South American species. Zootaxa 3771(1): 1-64.

SIMMONS RB \& POGUE MG. 2004. Redescription of Two Often-Confused Noctuid Pests, Copitarsia decolora and Copitarsia incommoda (Lepidoptera: Noctuidae: Cuculliinae). Ann Entomol Soc Am 97(6): 1159-1164.

USDA. 2019. World Agricultural Production. U S Dep Agr, Circular Series WAP 7-19: 1-30.

VENNETTE RC \& GOULD JR. 2006. A pest risk assessment for Copitarsia spp., insects associated with importation of commodities into the United States. Euphytica 148: 165-183.

VERA MA, ACOSTA G, MURÚA MG, CASMUZ AS, FADDA L \& GASTAMINZA L. 2018. Plagas no blanco de la soja Bt: Complejo de especies del género Spodoptera Guenée, 1852 (Lepidoptera: Noctuidae). Avance Agroindustrial 39(3): 26-27.

\section{How to cite}

SAN BLAS G, TULLI MC \& CARMONA DM. 2022. First report of a Copitarsia species (Lepidoptera. Noctuidae) damaging soybean crops, with identification key to most common pest species. An Acad Bras Cienc 94: e20191277. DOI 10.1590/0001-3765202220191277.

Manuscript received on October 16, 2019;

accepted for publication on March 18, 2020

\section{GERMÁN SAN BLAS}

https://orcid.org/0000-0002-3119-590X

\section{MARÍA C. TULLI ${ }^{2}$}

https://orcid.org/0000-0002-1962-0133

\section{DORA M. CARMONA ${ }^{3}$}

https://orcid.org/0000-0001-5836-9925

${ }^{1}$ Universidad Nacional de La Pampa, Facultad de Ciencias Exactas y Naturales, Instituto de Ciencias de la Tierra y Ambientales de La Pampa, Consejo Nacional de Investigaciones Científicas y Técnicas, AR-6300, Santa Rosa, La Pampa, Argentina

${ }^{2}$ Facultad de Ciencias Agrarias, Universidad Nacional de Mar del Plata (FCA-UNMdP), RN 226, Km. 73,5, Balcarce, Buenos Aires, Argentina

${ }^{3}$ Instituto Nacional de Tecnología Agropecuaria (INTA). RN 226, Km. 73,5, Balcarce, Buenos Aires, Argentina

\section{Correspondence to: Germán San Blas}

E-mail:gsanblas@exactas.unlpam.edu, argsanblas@exactas.unlpam.edu.ar

\section{Author contributions}

MCT and DMC collected and reared the material. GSB carried out the identification and conceptualized the work, all authors contributed to the writing of the manuscript.

\section{(cc) BY}

